\title{
Food sovereignty and farmland protection in the Municipal County of Antigonish, Nova Scotia
}

\author{
Greg Cameron ${ }^{a *}$ \\ Dalhousie University \\ David J. Connell ${ }^{\mathrm{b}}$ \\ University of Northern British Columbia
}

Submitted January 23, 2018 / Revised June 30 and October 15, 2020, and February 14, 2021 /

Accepted February 25, 2021 / Published online August 25, 2021

Citation: Cameron, G., \& Connell, D. J. (2021). Food sovereignty and farmland protection in the

Municipal County of Antigonish, Nova Scotia. Journal of Agriculture, Food Systems, and Community

Development, 10(4), 173-193. https://doi.org/10.5304/jafscd.2021.104.005

Copyright (C) 2021 by the Authors. Published by the Lyson Center for Civic Agriculture and Food Systems. Open access under CC-BY license.

\begin{abstract}
This case study of the Municipal County of Antigonish (MCA) in the Canadian province of Nova Scotia assessed the extent to which agricultural land use planning accommodates those societal interests seeking to embed food sovereignty at the municipal level. Data were collected through content analysis of legislative documents, key informant interviews, and a review of the grey literature. Results suggest that the relatively weak municipal planning system in place prioritizes private interests over the public interest in farmland protection. The resultant gaps in the
\end{abstract}

a* Corresponding author: Greg Cameron, Ph.D., Department of Business and Social Sciences, Faculty of Agriculture, Dalhousie University; 56-58 Rock Garden Road, P.O. Box 550; Truro, Nova Scotia B2N 5E3 Canada;

Gregory.Cameron@dal.ca

b David J. Connell, Ph.D., Department of Ecosystem Science and Management, University of Northern British Columbia, Prince George, Canada; David.Connell@unbc.ca legislative setup in the MCA further reveal that food sovereignty actors and/or ideas have little influence over municipal governance of farmland protection. Broader historical and contemporary trends in Nova Scotia and Canada at large suggest that farmland will continue to lose ground to forces intrinsic to the dominant policy paradigm of market liberalism. Concluding thoughts call for "bringing back the (Canadian) state" itself as central to constituting a new agricultural policy paradigm.

\section{Keywords}

Agricultural Land Use Planning, Farmland Protection, Policy Regimes, Food Sovereignty

\section{Funding Disclosure}

This paper is based on a Social Sciences and Humanities Research Council (SSHRC) of Canada-funded national project entitled Agricultural Land Use Planning in Canada. For more details on the national project, please visit http://www.aglup.org/ 


\section{Introduction}

Supporting food sovereignty and protecting farmland seem like compatible policies. However, at the local level, there appears to be a disconnect between the two. To gain insights into the relationship between these two areas of policy, this paper presents the results of a case study of agricultural land use planning in the Municipal County of Antigonish (MCA) in northern Nova Scotia (NS), Canada (Map 1). For our purposes, farmland protection centers on legislation by any level of government that governs the uses of agricultural land (e.g., laws, by-laws, regulations, and policies) while promoting agricultural uses. This understanding of farmland protection is distinct from farmland preservation, which encompasses broader programs, such as soil conservation or other environmental practices, as well as mechanisms available to private landowners, such as land trusts and easements, that restrict the rights to use agricultural land.

Policy regimes combine issues, ideas, interests, actors, and institutions in public policy and are potentially "messy" regarding their integration across institutional scales (Jochim \& May, 2010). Crossing multiple scales of governance, actors in agricultural policy regimes may include citizens, all levels of government, local organizations, professional organizations representing producers, farmers, unions, industry trade associations, and environmental groups, among others (Connell et al., 2013). This paper focuses on the policy regime of

\section{Map 1. Canada's Provinces and Territories}

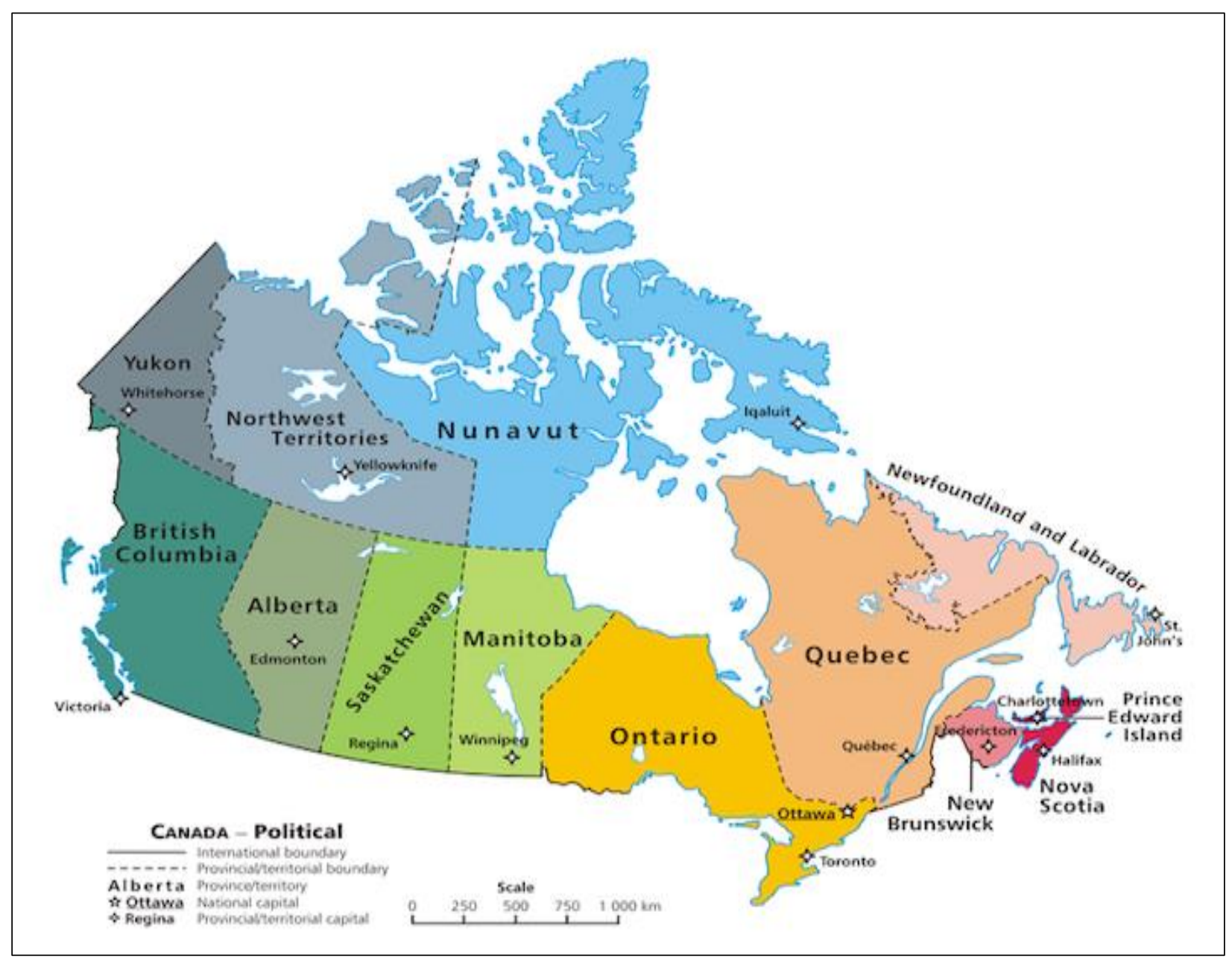

Source: Worldatlas.com. 
food sovereignty and its relationship to agricultural land use planning.

We follow Food Secure Canada's (n.d.) definition of food sovereignty: "Food sovereignty is the right of peoples to healthy and culturally appropriate food produced through ecologically sound and sustainable methods, and their right to define their own food and agriculture systems" (para. 1). The food sovereignty movement originated in the Global South; Canada's food sovereignty movement has its roots in the oil and food price shocks of the 1970s. Over many years, a network emerged in Canada called the People's Food Policy Project (PFPP) that eventually employed "food sovereignty" to build a national food policy agenda from 2008 to 2011 (Martin \& Andrée, 2017; Shawki, 2015). The National Farmers Union (NFU), a founding member of La Via Campesina, Food Secure Canada (FSC), and the Canadian Federation of Agriculture (CFA) are prominent food sovereignty actors nationally (Connell et al., 2013; Martin \& Andrée, 2017; Shawki, 2015). Food sovereigntyrelated initiatives have included farmers markets, community gardens, food cooperatives, and local food councils (Connell et al., 2013).

Food sovereignty's recent emergence in Canada reflects growing public concerns about the security and safety of the domestic food supply; urban household food insecurity; the struggles of family farms, debt, and concentration in both suppliers and retailers (AAFC, 2020); and the nonagricultural development of 4,633 sq. miles (1,199,941 hectares) of farmland since 1971, much of it on prime agricultural land under the Canada Land Inventory (Connell et al., 2013). These are among the trends that have galvanized food sovereignty actors to propose an overhaul of the current agri-food system in Canada. Yet the question of agricultural land use planning has received scant attention from proponents of food sovereignty who, by and large, do not connect local food systems to the Canadian land base (Connell et al., 2013).

Food sovereignty has been called an idea, concept, framework, mobilizing tactic, counternarrative, countermovement, political project, campaign, process, vision, or even a living organism (Desmarais, 2015). Food sovereignty's con- ceptual plasticity is both a strength and a weakness, given that its proponents have struggled to operationalize the concept across Canada's orders of government. The municipal level especially is a black box regarding agricultural land use planning, even though the effects of food system planning are most acutely felt locally in household food insecurity, waste management, climate impacts, agri-business failure, and agricultural land loss (Lavallée-Picard, 2016; Robert \& Mullinix, 2018; Shawki, 2015).

Studies at the municipal level in Canada, nevertheless, have advanced our understanding of food sovereignty concerns locally. Mendes' (2007) study on urban Vancouver calls for rethinking food planning by reframing scales and coordinating governance. Studies on food systems planning in British Columbia and Quebec have revealed strenuous community efforts to strengthen food system planning municipally (Lavallée-Picard, 2016). A case study from northern Manitoba has examined notions of Indigenous food sovereignty (Rudolph \& McLachlan, 2013).

However, gaps remain, both demographically and geographically, including in relation to marginalized urban populations, ethnic and newcomer groups, as well as in Canada's North, Frenchspeaking Canada (which has its own culture around food sovereignty), and Eastern Canada (Levkoe, 2013), where this case study is located. Through an examination of the convergences of food sovereignty, municipal governance, and farmland protection in the MCA, this study seeks to fill a regional and thematic gap.

\section{Objective and Methodology}

This case study's research objective is as follows:

To assess the extent to which agricultural land use planning accommodates those societal interests seeking to strengthen the food sovereignty policy regime at the local level of the MCA.

The main work, completed between 2015 and 2016, undertook document analyses and key informant interviews, with updates made during 2019_ 2021. The documents selected composed the 
provincial-municipal legislative framework for Nova Scotia (Table 1). We then analyzed these documents by searching for themes, key statements, and word placement, including whether the local legislative documents were enforceable or aspirational (Connell \& Cameron, 2016).

The follow-up questionnaire sought to elicit feedback on the legislative report as well as gain additional insights on what we may have missed, the strength of farmland protection in the MCA, and the extent to which food sovereignty ideas had changed agricultural land use planning (for the questionnaire, see Connell \& Cameron, 2016). Six semistructured interviews were conducted with

Table 1. Legislative Framework for Nova Scotia and the Municipal County of Antigonish

\begin{tabular}{|c|c|c|c|}
\hline & POLICY [Source] & LEGISLATION & GOVERNANCE \\
\hline 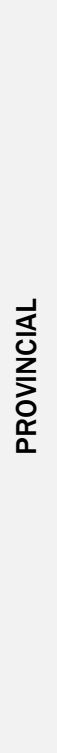 & $\begin{array}{l}\text { A Review of Initiatives Intended to } \\
\text { Conserve Agricultural Land (2008) } \\
\text { [Devanney \& Maynard, 2008] } \\
\text { Homegrown Success-a 10-year } \\
\text { plan for Agriculture (2010) } \\
\text { [Nova Scotia Department of } \\
\text { Agriculture, 2010] } \\
\text { Preservation of Agricultural Land in } \\
\text { NS (2010) } \\
\text { [Williams et al., 2010] } \\
\text { Protecting and Preserving } \\
\text { Agricultural Land in NS: A } \\
\text { Policy Framework } \\
\text { [Nova Scotia Department of } \\
\text { Agriculture, no date] }\end{array}$ & $\begin{array}{c}\text { [MGA] Municipal Government Act } \\
\text { of } 1998 \\
\text { [Nova Scotia Department of } \\
\text { Municipal Affairs and Housing } \\
\text { (NSDMAH), 2021] } \\
\text { Statement of Provincial Interest } \\
\text { Regarding Agricultural Land, } \\
\text { Schedule B } \\
\text { [Nova Scotia Department of } \\
\text { Municipal Affairs and Housing } \\
\text { (NSDMAH), 2021] } \\
\text { Agricultural Marshland } \\
\text { Conservation Act. (SNS 2000, } \\
\text { C. 22, s. 1) } \\
\text { [Nova Scotia Government (NSG), } \\
\text { 2000] } \\
\text { Farm Practices Act } \\
\text { [NSG, 2020b] }\end{array}$ & $\begin{array}{l}\text { Provincial Director of Planning } \\
\text { Nova Scotia Utilities and } \\
\text { Review Board }\end{array}$ \\
\hline
\end{tabular}

MGA C.18, s.193:

"The Governor in Council, on the recommendation of the Minister, may adopt or amend a statement of provincial interest necessary to protect the provincial interest in the use and development of land."

MGA 196 Provincial activities reasonably consistent

The activities of the Province shall be reasonably consistent with a statement of provincial interest.

MGA [Statement of Provincial Interest Regarding Agricultural Land, Schedule B]:

To protect agricultural land for the development of a viable and sustainable agriculture and food industry ... 1. Planning documents must identify agricultural lands within the planning area . . 2. Planning documents must address the protection of agricultural land.

\begin{tabular}{cccc}
\hline & & Municipal Planning Strategy for the & \\
Cunicipal County of Antigonish & Central Antigonish Plan Area & Central Antigonish Area \\
(MCA) Integrated Community & Advisory Committee \\
Sustainability Plan (ICSP) & [MCA, 2013a] & \\
[MCA, 2009] & Central Antigonish Land Use By-law & \\
& [MCA, 2013b] & & \\
\hline
\end{tabular}

Italic: Acts (provincial laws), by-laws (local government laws, e.g., official municipal plan)

Bold: Enforceable policy, regulations pursuant to acts

Plain text: Aspirational policy at all levels 
provincial and municipal planners, as well as a representative of a farmers' organization and a food security organization in the MCA and Town of Antigonish.

A supportive government planner in the NS Department of Municipal Affairs and Housing (NSDMAH), who had studied under one of the national team leaders of the SSHRC project at the University of Guelph in southern Ontario, facilitated contacts with government and farmer representatives. The first author's links in the Town of Antigonish, both to extended family and to St. Francis Xavier University (St. FXU), facilitated identifying the food security organization representative. These six key informants were well conversant with agricultural land use planning and/or food sovereignty issues. To maintain confidentiality, the interviews are numbered from one to six. A review of media and grey literature on the MCA rounded off the data-gathering techniques.

The paper is organized as follows: Part 1 sets the theoretical and methodological context for the case study on food sovereignty and farmland protection in the MCA. The results of the paper compose Parts 2 through 4. Part 2 is technical and surveys the planning system for farmland protection in Nova Scotia and the MCA as well as outlining the local farming context. Part 3 reveals a planning system that prioritizes the private disposal of farmland for non-agricultural uses over its protection for public interests. Part 4 notes the virtual absence of the food sovereignty policy regime in the MCA's documentation. It also shares the perspectives of planners, farmers, and civic actors on this lack of presence in planning documents and ways forward to strengthen food sovereignty in the MCA. The final section explores the wider implications of this study for "bringing back the (Canadian) state" as a site itself for food system transformation.

\section{Agricultural Land Use Planning in Nova Scotia}

A legislative framework includes legislation, policies, and governance structures. Nova Scotia's most important legislative document is the Municipal Government Act (MGA) of 1998, governed by the Department of Municipal Affairs and the Provin- cial Director of Planning, listed in the provincial legislative cell in Table 1.

The provisions for provincial land use policy are guided by Statements of Provincial Interest (SPIs) that include the protection of high-quality farmland, known floodplains, and municipal drinking water; the provision of affordable housing; and the best use of infrastructure (NSDMAH, 2021). Development undertaken by the province and municipalities should be "reasonably consistent" with the SPI (NSDMAH, 2021). These guidelines were intended to assist in municipal decisionmaking processes. Section 208 provides that planning documents are subject to review by the provincial director of planning and would go to the minister if the planning document affects an SPI (NSDMAH, 2021).

The specific SPI relevant to farmland seeks "to protect agricultural land for the development of a viable and sustainable agriculture and food industry" (NSDMAH, 2021, p. 296). Planning documents must both identify and address the protection of agricultural land and balance these with non-agricultural uses (see NSDMAH, 2021). The SPI "applies to all active agricultural land and land with agricultural potential in the Province" (NSDMAH, 2021, p. 296)—although "active" and "potential" are not defined. For municipalities that opt to do planning, the MGA 1998, Section 213 states that "The purpose of a municipal planning strategy is to provide statements of policy ... to guide the development and management of the municipality. .." (NSDMAH, 2021, p. 129). One interviewee described the farmland protection language in the SPI as "wishy-washy" but added that at the time, the planners hoped that an incremental approach would encourage municipalities to adopt planning (Interview \#1).

A municipal planning strategy (MPS) may take various forms, including an intermunicipal planning strategy or a secondary planning strategy. A land use by-law (LUB) is a companion document to an MPS that allows a municipality to enforce its vision as defined by the MPS. Were an MPS not reasonably consistent with the SPI, it would be flagged for refusal (Interview \#2). However, an amendment to the LUB, such as a rezoning request, would not go to the province for approval 
but could be appealed to the Utilities and Review Board (Nova Scotia URB, 2020) (see Table 1 under Provincial Governance). Were a municipality in noncompliance with the SPI, it would then be notified that compliance would be expected within a reasonable length of time.

Planning in relation to farmland protection across rural municipalities in Nova Scotia is a patchwork of comprehensive, single, district, and no planning systems (Map 2). Farmland protection is divided into the following categories:
i. Zoning to protect
ii. Permissive zoning
iii. No zoning

"No zoning" means that there is nothing in place regarding land use without a plan, except for building codes. For example, in a non-planning context, one could find a bottling recycling plant next to a residential house or farm (Interview \#1). For those rural municipalities that do undertake planning, most only "recognize" but do not "protect" agricultural land in their municipal planning strategies (permissive zoning). For comprehensive planning, a rural municipality must address all the SPIs in the MGA 1998. "Comprehensive" means the plan deals with a variety of land use issues together (which has nothing to do with the area covered by the plan and could be on a district level as well), such that land is identified and given

Map 2. County Names and Boundaries of Nova Scotia, Canada

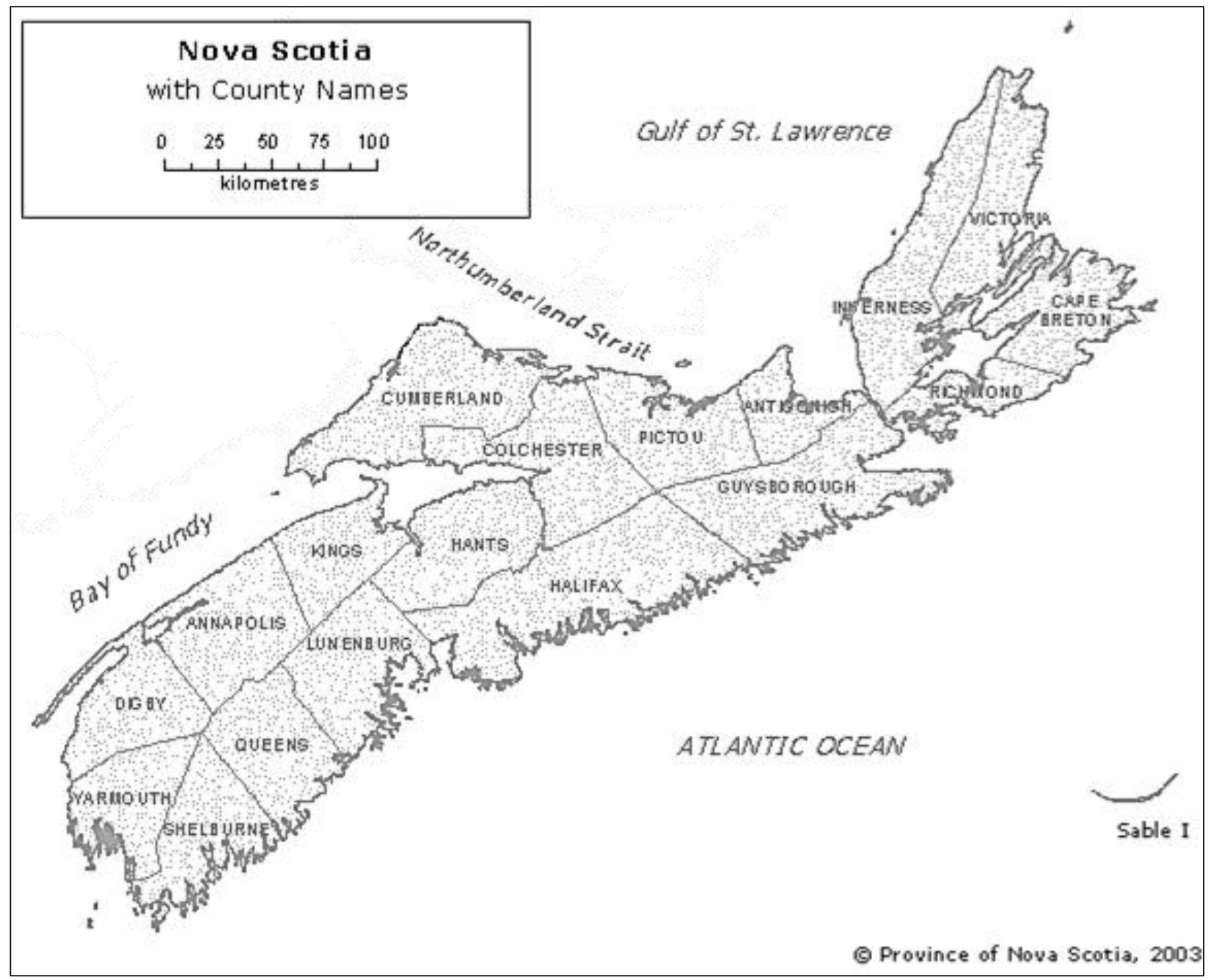

Source: Map of Nova Scotia, https://bestmapof.com/map-of-nova-scotia.html [no longer online]. 
specific zoning to protect it (Interview \#2).

To protect farmland, a municipal council must have permission for change of use, and once "protected," must follow the MGA 1998's SPI. Comprehensive planning that protects agricultural land across a whole municipality is found only in King's County, a critically important subregion of Nova Scotia's agricultural sector that includes the Annapolis Valley (Connell \& Cameron, 2016). The MCA is one of the partially planned municipalities in the province (permissive zoning), making it an interesting case study. Most rural counties are typically unplanned or have only permissive zoning (Cameron \& Connell, 2016). As shown in Map 3, much of the Class 2 land in NS (there is no Class 1 in the province) is unprotected. For a list of all the counties and their level of protection, see NS Government Agricultural Land Protection (NSG, 2020a).

The MCA, governed by a council of $10 \mathrm{mem}$ bers, provides a wide range of municipal services and is assisted in the discharge of its duties by the Eastern District Planning Commission (EDPC), whose mandate (as per MGA 1998, Section 255) is to provide intermunicipal services, such as assistance with planning documents, and building inspection services. Current land use planning in the MCA was established as needed in different sections of the MCA. Currently, the Eastern, Central, Fringe (adjacent to Town), and KeppochBeaver Mountain municipal plans regulate development for most of the area and population of the MCA (Interview \#4). The Town of Antigonish, a separate entity, is governed independently of the MCA (Malhotra, 2009). Below we provide the rural and farming context in the MCA to situate the local planning dynamic around farmland protection and food sovereignty.

\section{Farming and Food Systems in the MCA}

Located in northern Nova Scotia (Map 4), the MCA covers 1,458 square kilometers (563 square miles). It consists of 26 small rural settlement areas (such as hamlets), with approximately 15,000 people, most located close to the Town of Antigonish (approximating 4,400 people) and along the TransCanada Highway. The MCA is bounded by Pictou County to the west, the Canso Strait to the east, Guysborough County to the south, and the North- umberland Strait to the north. The South River and West River are the biggest rivers that run through the county. The less populated southern part of the MCA is primarily highlands. Antigonish's climate is moderate, with cold winters and temperate summers.

The economic drivers of the MCA, and the town, include forestry, fisheries, the trades, retail, and the health and education sectors, notably Saint Martha's Regional Hospital and St. FXU. Tourists are also drawn to MCA's beaches along the Northumberland Coast and its historical and cultural amenities - particularly its Celtic heritage, celebrated in the annual Antigonish Highland Games since the 1860s (Campey, 2007). Agriculture (especially in the central area) in the MCA remains productive and employed roughly 5,300 people in 2013 (NSFA, 2012a).

Trends in agriculture in Nova Scotia mirror those of North America, generally speaking, with concentration in farm ownership in tandem with industrialization and urbanization. From a peak of 60,000 farms in 1891, there were no more than 24,000 left in Nova Scotia by 1951, and many were part-time or subsistence (Mackinnon, 1996). Technological advances, coupled with the transportation revolution, made it economically feasible to import fruit, grains, meat, etc., from distant world markets. By the 1950s, the province was experiencing deficits in foodstuffs despite robust local production (MacKinnon, 1996).

Today it is estimated that only $8.4 \%$ of Nova Scotian food consumption comes from Nova Scotian farms (NSFA, 2020). The most recent 2016 national census counted 3,478 farms in Nova Scotia, a 10.9\% decline from the 2011 census, with a concomitant $10.1 \%$ drop in total acreage to 0.9 million acres (Statistics Canada, 2016). Nova Scotia remains among Canada's most rural provinces. In 2016, 34\% of Nova Scotians lived in rural and small-town communities (R. Bollman, personal communication, June 2017). The population generally declines the further one goes from Halifax, the provincial capital (Gibson et al., 2015).

The MCA accounts for approximately $6 \%$ of Nova Scotia's agricultural land and $4.7 \%$ of its Class 2 soil and possesses moderately good soils, including Class 3 and Class 4 agricultural lands 


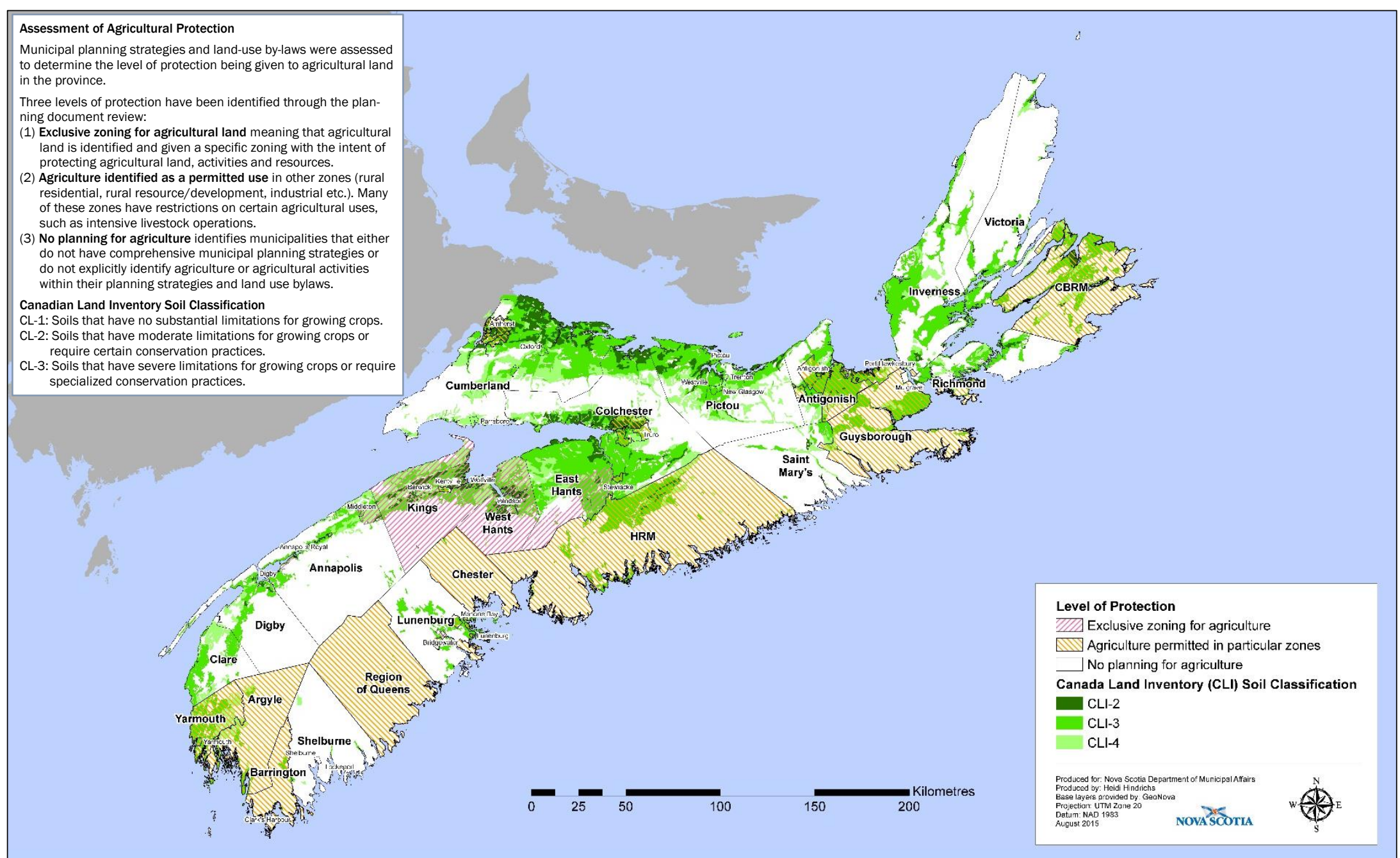

Source: Geo-Nova Scotia, 2015. 


\section{Map 4. Location of the Municipal County of Antigonish, Nova Scotia, Canada}

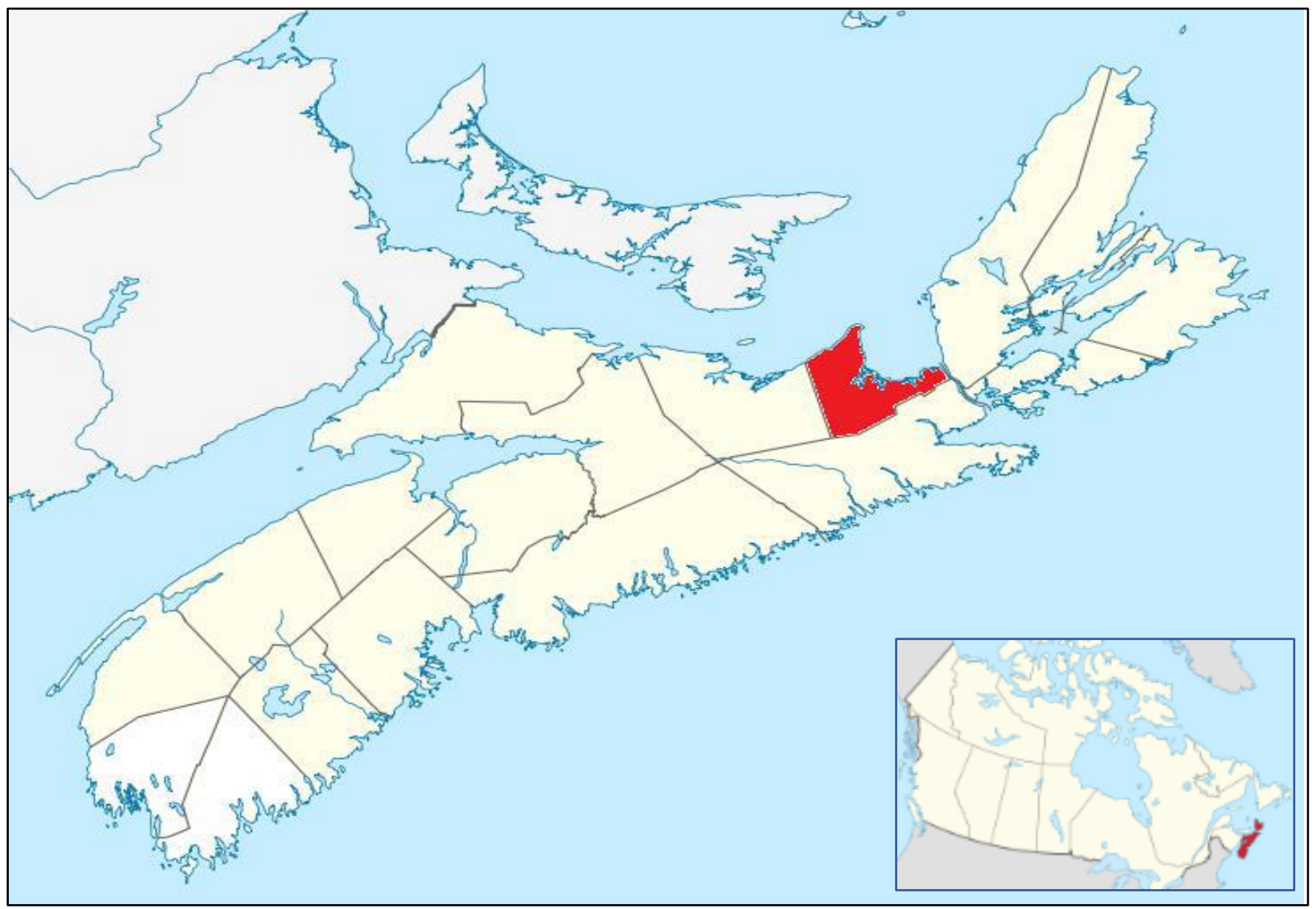

Source: Nova Scotia Federation of Agriculture, Statistical Profile of Antigonish County, 2012a.

(MCA, 2013a). Estimates are that $31 \%$ of Class 2 soil in the MCA are being farmed (Devanney, 2010). In 2011, the average farm size in Antigonish County was 274 acres (111 ha), larger than the provincial average of 260 acres (105 ha); around 35\% of farms were less than 129 acres (52 ha) (NSFA, 2012a). Farms in the MCA reported a total of approximately CA $\$ 26.1$ million in farm receipts in 2010; however, most individual farms reported revenues of less than CA $\$ 50,00$ (AFSC, 2013; MCA, 2013a; NSFA, 2012a). There are 226 registered census farms in the MCA, concentrated in cattle ranching, floriculture, and Christmas trees, as well as around 34 dairy farms (AFSC, 2013; NSFA 2012a). ${ }^{1}$

The MCA's farm sector faces challenges common across Canada, such as restrictive marketing channels, labor supply bottlenecks, tightening regulations, static farm gate prices, an aging farm population, lack of new farm entrants, and competition with cheap imports (AFSC, 2013). For example, cattle ranching has dramatically decreased since 2006, with farm numbers dropping from 93 to 74 $(-20.43 \%)$ (NSFA, 2012a). Beef farmers have struggled to compete with those in Western Canada in terms of grain supply feed. Grass-fed pasture, however, may present niche market opportunities for Nova Scotian beef farmers (AFSC, 2013). These broad trends have hurt all farm subsectors outside of supply management. Established in the 1970s for the dairy, chicken, egg, and turkey industries, the supply management system is based on three pillars: the control of prices, the control of supply, and protection from foreign competition.

\footnotetext{
${ }^{1}$ For the complete definition of a census farm, see Statistics Canada (2016).
} 
These operate under national supply management systems controlled by national bodies and provincial commodity marketing boards (Library of Parliament, 2016).

A nascent local food movement in the MCA and Town of Antigonish comprises food cooperatives, U-picks, community supported agriculture (CSA) operations, farm accommodations, and an expanding blueberry sector covering 534 ha, often on disused farmed land (Interview \#6). The town's farmers market had roughly 900 visitors, 60 vendors, and CA $\$ 600,000$ in sales in 2010 (NSFA 2012a). Non-census "kitchen" garden farmers, numbering somewhere between 20 and 50 people usually working on less than 10 acres (4 ha), frequently sell their produce locally and in town.

All these issues in the MCA-the decline of beef farming, the supply management system, local niche markets for conventional farms, and prospects for the fledgling local food movement—are reflected in the case study results below.

\section{The MCA and Farmland Protection}

We selected an example of agricultural land use planning in the MCA from the Central Plan Area for this study because of its large size and extensive rural base, and the relatively recent (2013) passing of its Municipal Planning Strategy. The Central Antigonish Plan Area (Map 5), situated between the Eastern Region Plan Area and the Fringe Plan Area, is composed primarily of low-density rural development situated alongside waterways and highways, with some local commercial, small-scale industrial, agricultural, forestry, fishing, and tourism enterprises (MCA, 2013a). The MCA recognizes the visual and economic benefits that the natural assets of the Central Antigonish District present to the local economy, area residents, and visitors (MCA, 2013a). And while the MCA MPS encourages non-agricultural development in designated hamlets to avoid land use conflicts, the council inserts the qualifier "where possible," suggesting that the commitment to do so may be secondary to allowing non-agricultural development on farmland (MCA, 2013a, pp. 10, 19).

The MCA is aware of the controversies surrounding the protection of farmland. The MPS says that there are development pressures on farmland, including from the farming community itself, which calls for the council to consider the issue of farmland loss further, either through a countywide planning exercise or through additional investigation into regulations or incentives. However, by side-stepping this core issue, precedents may have been set in favor of private interests. The MPS even appears to question the right of government to infringe upon private landowners:

... Council does not intend to prohibit all residential buildings in the Central Antigonish Plan Area on farmland, as concern has been raised about limiting the development rights of farmers who may wish to develop part of their lands in the future for uses other than agricultural ones. (MCA, 2013a, p. 19)

In response to our findings, the MCA stated its belief that the council acts within the province's legislative framework and policies and by-laws that it has created for itself. As such, it wishes to maintain flexibility outside the SPI (Interview \#4).

The Central Antigonish Area Advisory Committee also does not appear to play an active role in accommodating multiple interests around farmland protection. Nicol (2006) notes that the MCA does not have a strong history of land use planning in general, including in coastal protection. The planning system in place in the MCA may be contributing to the fragmentation of farmland in rural areas, especially close to the coast along the Northumberland Strait, Saint Georges Bay, and Lochaber (three areas without planning in place), as well as from urban encroachment from the Town of Antigonish into the MCA (Interview \#6).

Our selected case study of an actual land use decision represents a controversial example of rural fragmentation in the Eastern Region Plan Area, a neighboring plan area to the Central Antigonish District (see Map 5, top right). A farmer in Tracadie, on St. Georges Bay, applied to rezone parts of his agricultural land from Rural (R-1), low impact development, to Residential Multi-Unit (R2), higher impact development, to allow for the construction of nine single-unit dwellings on a single parcel of land (7.4 ha/18.3 acres), along with a road. The site was to be a bare-land condomin- 


\section{Map 5. Antigonish Central Plan Area, MCA, Nova Scotia, Canada}

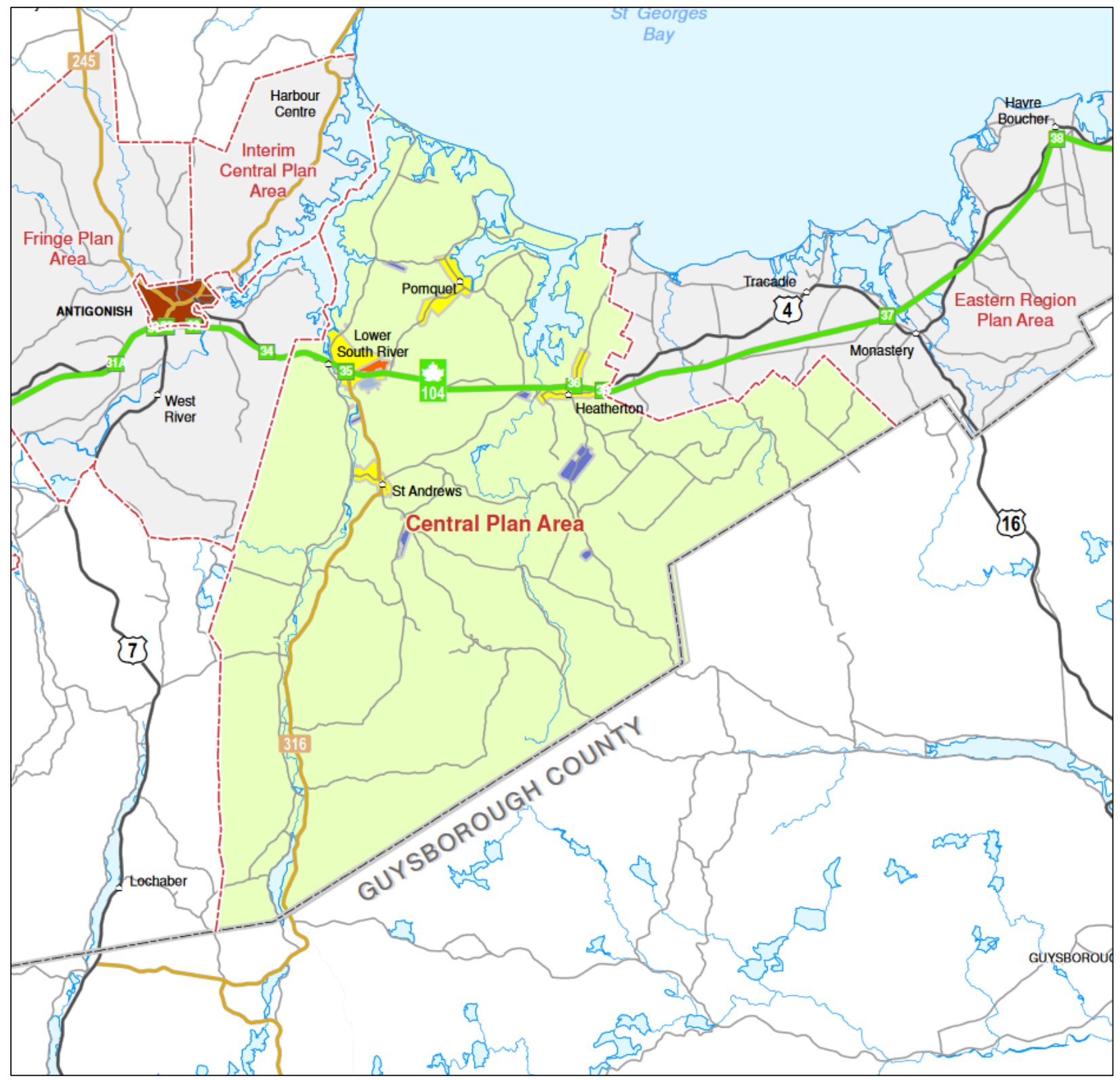

Source: Eastern District Planning Commission (EDPC), 2015.

ium on a former beef farm (EDPC, 2014).

The MCA overwhelmingly passed the rezoning application (there was also apparently a recusal on council due to a conflict of interest). The EDPC, employing a narrow set of criteria based on the weak protection contained in the Eastern Region Plan Area documents, recommended the rezoning request (Interview \#3). While the Eastern Plan Area notes the importance of agriculture and the protection of Class 2 and 3 soil (MCA, 1994), there is even less farmland protection language than in the Central Plan Area MPS. There also appeared to have been no discussions in council about this development taking place on Class 2 soil (see the NSDMAH, 2021, Section 250). Coastal cottages are often built on Class 2 farmland (Map 6: see red color classification, which includes the Tracadie area). 


\section{Map 6. Agricultural Capability in Antigonish County, Nova Scotia, Canada}

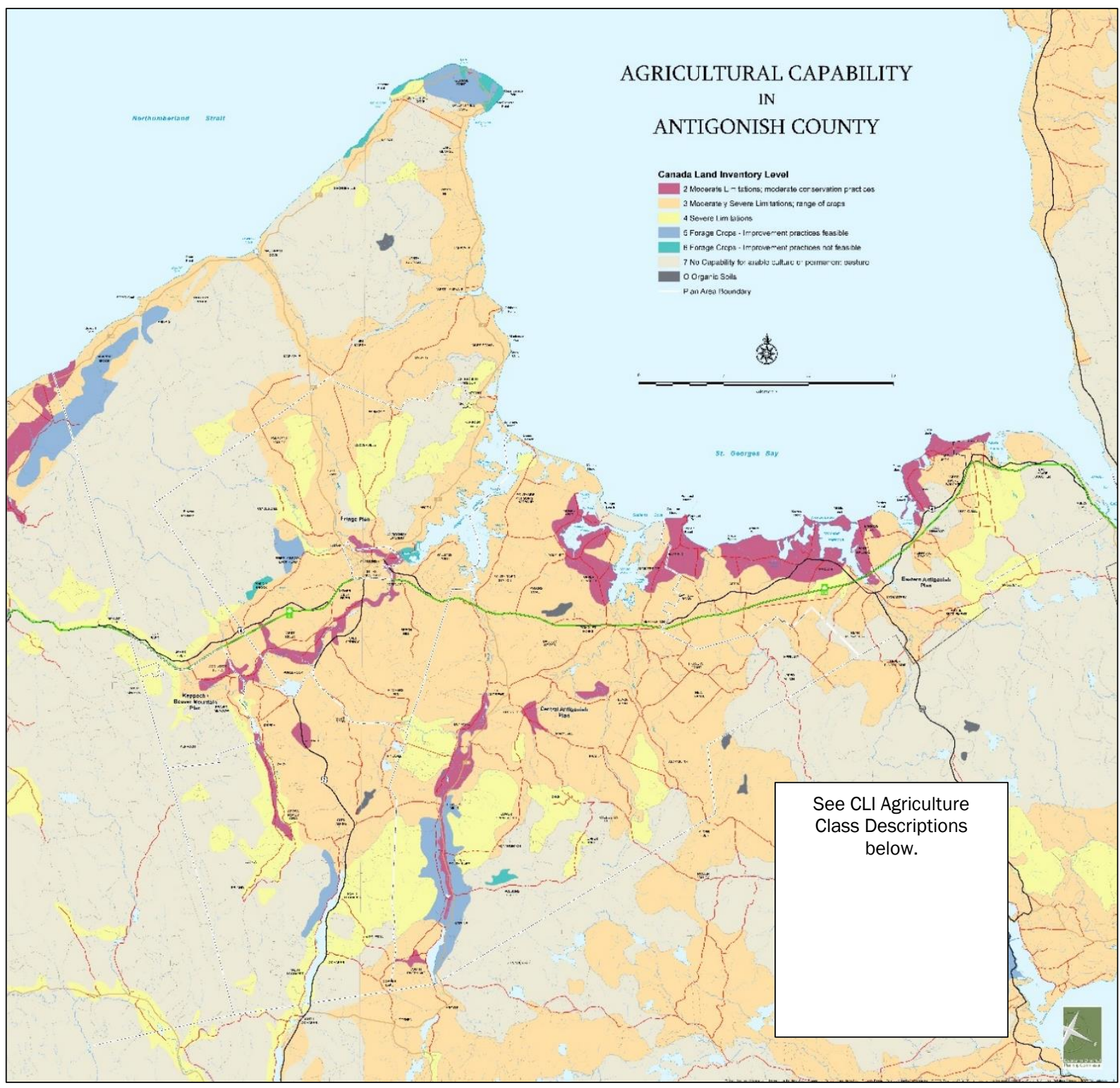

- Class 1 soils have no significant limitations in use for crops. The soils are deep, are well to imperfectly drained, hold moisture well, and in the virgin state were well supplied with plant nutrients. They can be managed and cropped without difficulty. Under good management they are moderately high to high in productivity for a wide range of field crops.

- Class 2 soils have moderate limitations that restrict the range of crops or require moderate conservation practices. The soils are deep and hold moisture well. Under good management they are moderately high to high in productivity for a fairly wide range of crops.

- Class 3 soils have moderately severe limitations that restrict the range of crops or require special conservation practices. The limitations are more severe than for Class 2 soils. They affect one or more of the following practices: timing and ease of tillage, planting and harvesting, choice of crops, and method of conservation. Under good management they are fair to moderately high in productivity for a fair range of crops.

- Class 4 soils have severe limitations that restrict the range of crops or require special conservation practices, or both. The limitations seriously affect one or more of the following practices: timing and ease of tillage, planting and harvesting, choice of crops, and method of conservation. The soils are low to fair in productivity for a fair range of crops but may have high productivity for a specially adapted crop.

- Class $\mathbf{5}$ soils have very severe limitations that restrict their capability to producing perennial forage crops, and improvement practices are feasible. The soils are not capable of use for sustained production of annual field crops. The soils are capable of producing native or tame species of perennial forage plants, and may be improved by use of farm machinery. The improvement practices may include clearing of bush, cultivation, seeding, fertilizing or water control.

- Class 6 soils are capable only of producing perennial forage crops, and improvement practices are not feasible.The soils provide some sustained grazing for farm animals, but the limitations are so severe that improvement by use of farm machinery is impractical, terrain may be unsuitable for use of farm machinery, the soils may not respond to improvement, or the grazing season may be very short.

- Class 7 soils have no capability for arable culture or permanent pasture. This class also includes rock land, other non-soil areas, and bodies of water too small to show on maps at mapping scale.

- Class 0: Organic soils. (Not placed in capability classes.)

Map source: Eastern District Planning Commission (EDPC), 2015. 
Plate 1. Farmland for Sale in the Eastern Plan Area, Municipal County of Antigonish, Nova Scotia, Canada, 2015

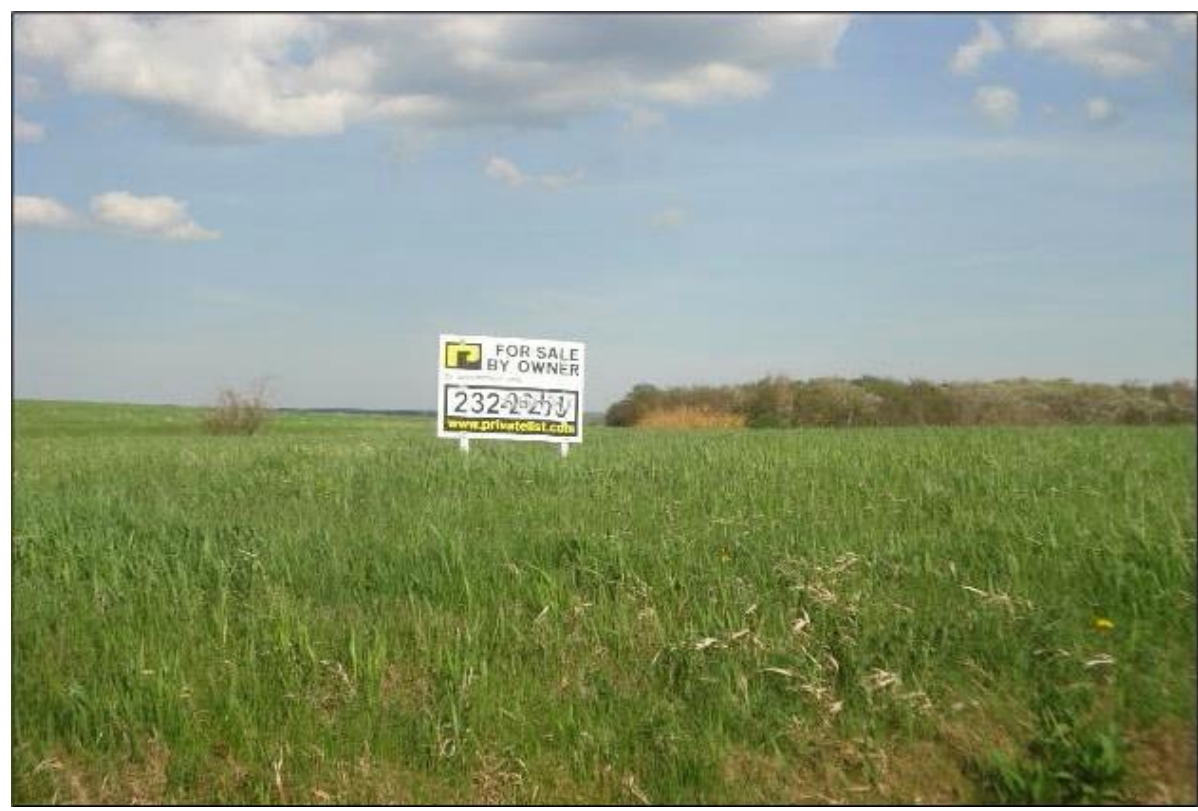

Source: G. Cameron, 2015.

\section{Plate 2. Farmland for Sale in the Eastern Plan Area, Municipal County of} Antigonish, Nova Scotia, Canada, 2015

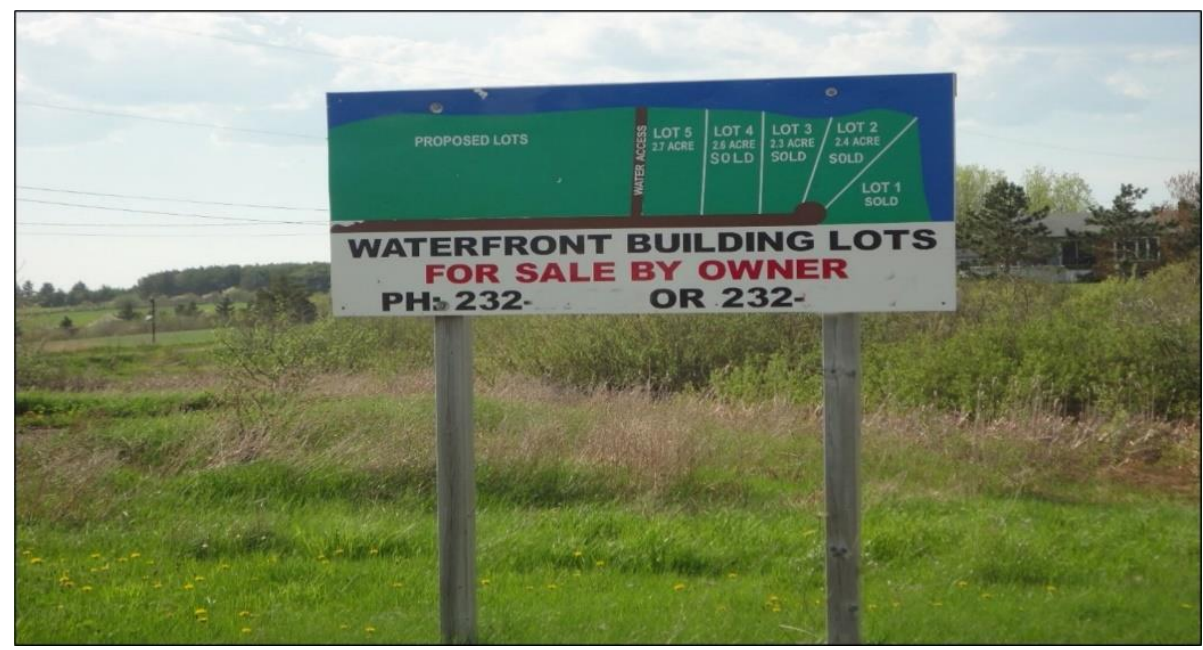

Source: G. Cameron, 2015.

Local citizens who opposed the MCA's decision invoked the SPIs and called into question the process by which the MCA had reviewed the rezoning application (The Casket, 2013). A farmer living near the proposed site, invoking the "right to farm" for fear of nuisance complaints, appealed to the Utilities and Review Board, which in turn ruled that the MCA did reasonably carry out the intent of the Eastern Plan Area MPS. The province, in its 2013 decision, agreed with the MCA that development pressures in Tracadie did not warrant strict protection given the extensive farmland base in the MCA, but should things change in the future, the MPS should be amended accordingly. The minister subsequently approved the farmerdeveloper's request according to MGA 1998, Section 208 (3), despite potentially conflicting with the SPI.

Farmland can also be developed without going to the MCA if it is done within the R-1 zone (permissive zoning), a designation that allows structures including one- and two-unit residential development, mobile homes on individual lots, senior citizens' housing, institutional and recreational uses, and generalized commercial uses, in addition to forestry, fishing, and agriculture (MCA, 1994). Plates 1-3 show another housing development project under construction in Tracadie occurring under the R-1 designation, by the same farmer-developer.

One interviewee opined that the province should not have approved the MPS Central, Fringe, and Eastern plans in the first place because of the way these documents were written without exclusive zoning for agricultural land; instead, the province simply signed off on the current MPS plans (Interview \#1). 
With the Tracadie case in mind, one interviewee said that the MCA appears not to know what to do to make farmland protection a priority:

It is like the Wild West; you do something until crap happens. ... Farmland protection is in uncharted territory. ... I don't think municipal politicians are tough enough to enforce it. If I wanted to rezone at council, I don't think I would have such a problem. (Interview \#1)

Another interviewee said that it is status quo in the planning world, and in fact, planners are often just reacting to problems on the ground (Interview \#3). Farmland loss is not officially tracked, and hence the extent of the developmental impact on the land base is difficult to ascertain (Interview \#3). And while foreign ownership of farmland is not yet a major issue in Nova Scotia, as it is in western Canada, cottage properties dot coastal NS, including the Bras d'Or lakes of Cape Breton and along the Northumberland shore (as seen at the top of Map 3), where weak regulations provide only the chimera of municipal farmland protection (Interview \#3). The Tracadie example may be just the tip of the iceberg of land fragmentation in contemporary rural Nova Scotia.

While there are general acknowledgments that municipalities need to be consistent with the SPI in the MGA 1998, their detailed elaboration in the MPS and LUB in the MCA's Central Plan area, and other district plans, are weakly integrated with the provincial MGA 1998. The result is that farmland remains vulnerable to non-agricultural development. Certainly, the MCA's recognition of the historical importance of farming in Antigonish could slow down the politically sensitive process of farmland rezoning. Farming and farmers remain a key pillar of the local economy and community in both town and county. But farmland fragmentation is a generalized problem beyond Antigonish.

Across Nova Scotia's rural municipalities, the SPI is not applied consistently, and too many gaps occur, with planning in the hands of vastly different municipal approaches without strong provincial oversight (Connell, 2016). Further, the SPI does not apply where there is an absence of land use planning, which puts those municipalities who do land use planning at a disadvantage and holds them to a higher standard than those who do not plan. Interestingly, another interviewee said that farmers are pragmatic and would most likely accept more stringent agricultural land use planning systems in Nova Scotia if the SPI were applied across all rural municipalities (Interview \#2). In general, the interviews revealed that to some extent, each level of government was leaving it to the other level to tighten up oversight of the SPI. Thus, while the MGA 1998 creates a relatively strong provincial legislative framework for protecting farmland, there appeared to be a de-linking between the provincial and municipal levels regarding the detailed incorporation of the SPI on agricultural land into municipal planning documents.

The authority of the province to reform and 
more dynamically integrate the levels, or to compel municipalities to address the full protection of agricultural land, remains an important tool (see the Williams report noted in Table 1). Since this research was completed, some reforms have been put in place. In 2018 the Nova Scotia government passed Bill 58, which mandates all municipalities to adopt planning and fulfill minimum requirements, apparently within a three-year time frame (NSG, 2018). However, it appears the bill would not compel the MCA itself to strengthen current farmland protection. ${ }^{2}$

\section{Food Sovereignty and Farmland Protection}

There were no direct references to the food sovereignty policy regime in any of the MCA's legislative documents. Therefore there is no basis by which to extrapolate food sovereignty issues from the local planning system documentation.

The closest reference to food sovereignty in the MCA is an aspirational, top-down policy piece called the Integrated Community Sustainability Plan (ICSP) (MCA, 2009) (commonly adopted by Canadian municipalities to access extra federal tax funds), which covers the MCA as a whole (Malhotra, 2009) (see the ICSP under Policy in Table 1). The ICSP's highest priorities include lower dependence on food imports, greater availability of local food, local procurement by grocery chains, promotion of local cooperatives, encouragement of community gardens, and enhancement of local meat inspection systems (Malhotra, 2009). Yet there is no tight link between the ICSP and the MCA's planning documents; hence the ICSP document has a limited presence in legislative documents such as the Central Plan Area MPS.

An MCA representative defended the weak legislative presence of food sovereignty by noting that a staff person has been responsible for implementing aspects of the ICSP into the processes of the MCA, including sustainable procurement and alternative energy (Interview \#4). While food sovereignty has not been reflected in actual planning documents, the planner added that these perspec- tives come into other municipal activities such as the support of the farmers markets, the local 4-H Club, and the Antigonish Agricultural Exhibition (Ekistics Planning and Design, 2010). The planner said that the activities above are doing well on their own terms:

Municipal Council has not seen the need to be that interventionist in regard to introducing food sovereignty. Nor have we been approached to be more interventionist by the community. (Interview \#4)

Another interviewee said that food sovereignty would not be an idea that most councilors- the majority having "run-of-the-mill" backgroundswould even be familiar with (Interview \#5). A provincial planner remarked that a shift toward food sovereignty is nowhere in sight, with planning issues being much more basic than that (Interview \#3).

The Nova Scotia Federation of Agriculture, a farmers' organization founded in 1895 that represents the majority of agricultural production in NS (and is a member of the Canadian Federation of Agriculture), and the Antigonish Food Security Coalition are the main food sovereignty actors in the broader community of the MCA. We will introduce each in turn and detail their responses to our findings.

The Antigonish/Guysborough (see Map 2) section of the provincial NSFA has approximately 140 members and represents active farmers and farmers wishing to sell their farm properties for non-agricultural use. The divisions surrounding farmland protection can be found in the local branch of the NSFA, including supply management/non-supply management farmers; crops/ livestock farmers; big farmers/small farmers; and younger/older farmers (Interview \#5). As the NSFA representative put it:

Does the NSFA support the status quo? Or see land as a retirement "nest-egg"? Or prioritize the future of the next generation and

\footnotetext{
2 The first author made a return visit in June 2021 to the two Tracadie sites in the Eastern Plan Area and found little evidence of building construction at either site. However the farmer-developer's nearby farm enterprise and remaining acreage had been listed on the open real estate market.
} 
the importance of preserving farmland? We must feed our families as businessmen, but at the end of the day we need to look beyond our immediate position. (Interview \#5)

The NSFA is caught in the middle, given its mandate to promote farming in general as well as to protect the interests of individual farmers who may want to sell their land at market value prices.

This, of course, is a difficult issue well beyond the MCA. Most farmers are land rich and cash poor and prefer to see their land stay in agricultural production if there were family members or new entrants with the capital to purchase their farms. Short of this, farmers see their farms as their main financial source for retirement. The MCA's view is that land is a farmer's "nest egg," and if they have no successors, then selling their land is seen as one of the remaining viable options; this reality is the challenge facing the county (Interview \#4). ${ }^{3}$ Another interviewee opined that the government needs to take a stand as to whether land is a resource like oil, or if it is not: "Why should a farmer be asked to preserve a resource that benefits everyone and not be compensated for it?" (Interview \#2).

The Provincial NSFA supports a provincially operated compensation program to ensure that farm owners receive adequate compensation for land where land values are adversely affected by agricultural land use restrictions (NSFA, 2012b). But short of establishing a taxpayer-funded program, which may be controversial to the public, it is unclear whether the NSFA can play an authoritative role in stemming farmland loss in Nova Scotia. Moreover, the more food sovereigntyaligned National Farmers Union does not have a district presence in Nova Scotia (NFU, 2020).

As noted in the NSFA data above, conventional agriculture in the MCA has had only limited growth in recent years or has even decreased in certain subsectors, such as cattle ranching, which undoubtedly would contribute to farmers' decisions to parcel and/or sell off their farm proper- ties. The implications of free trade agreements for local food production were raised:

Free trade has impacted farmland preservation for sure, otherwise people would be making money and not selling farms, or seeing the young people going out West. ... We need to get to the root causes of the loss of farmland -beyond farmland preservation itself.

(Interview \#6)

Several interviewees felt that the province should reconsider how current agricultural policy, broadly speaking, could better serve the public interest in farmland protection.

Optimism was also expressed. The NSFA representative said that there is a change in how people think about the local agricultural land base. People in the Town of Antigonish like the idea of local food, farmers markets, organic produce, etc., and that even conventional farms have been switching to organic crops and grass-fed beef. He mentioned a neighbor, hitherto a conventional farmer, who now has grass-fed cattle, sheep, and pigs on fields. This would have been unthinkable 20 years ago but is more common today (Interview \#5).

An interviewee explicitly linked supply management to food sovereignty, bringing government agricultural policy into focus, when they articulated the following opinion:

It [supply management] keeps production, distribution, and consumption local. So many people are connected to the supply chain like trucks, processing, and there are no booms and busts like oil. Milk is steady. (Interview \#5)

Canadian scholars have also explored food sovereignty's application to supply management since it protects family farms and restricts unnecessary imports. Reforms have been suggested concerning new entrants into the supply-managed sectors (Desmarais \& Wittman, 2014). Mount's

\footnotetext{
${ }^{3}$ A close relative of the first author from the Town of Antigonish colloquially quipped that it is hard to control farmland sell-off, because at the end of the day a farmer wants to get the highest price for his land and then hope someone looks after him in an old age home (informal discussion, June 2015).
} 
(2017) study of small chicken farmers in Ontario showed successful integration into the supply management system.

The Antigonish Food Security Coalition (AFSC), formed in 2009, covers both the Town of Antigonish and the MCA; it has provincial, municipal, and university (St. FXU) representation. As part of a wider town-based network called Sustainable Antigonish, the AFSC advocates for a sustainable food system. Its activities include community kitchens, local food hubs, and a presence at the farmers market. Collaborative efforts have also been made to reach new farmers through an apprenticeship program sponsored by the Sisters of St. Martha, a Catholic religious congregation that mentors people interested in producing food for local restaurants (Interview \#6).

There is virtually no mention of agricultural land use planning in the AFSC's otherwise excellent local food system report (AFSC, 2013). And while the AFSC does work with the town council on local food policy, this work is not directly related to farmland protection (Interview \#6). The AFSC has little actual influence inside the MCA in respect to agricultural land use planning. This lack of a food sovereignty presence could also be due to the local perception that farmland is plentiful or at least not under immediate threat in the MCA (Interviews \#3, \#4).

In sum, there was virtually no food sovereignty presence in the governance of the MCA. The NSFA was divided on the issue, and the AFSC had not explicitly connected the local food system to the land base. Small-scale, alternative farmers appeared to be few and far between and not politically organized beyond the farm level in the MCA.

\section{Discussion and Conclusion}

We sought to assess the extent to which agricultural land use planning accommodates those societal interests seeking to strengthen food sovereignty in the MCA. Trends on the ground indicate ongoing farmland loss based on private interests in Nova Scotia, while the food sovereignty policy regime remains locked out of government(s). What then are the broader implications of this case study?

This study revealed that food sovereignty does have some societal presence in the MCA. The PFPP process in Canada sought to build links across at least three sets of class contradictions: the producer/consumer connection; the Indigenous/ non- Indigenous relationship; and the North/ South geopolitical divide: "All of this is needed well before deliberative dialogue can even begin with many of the 'mainstream' policy actors discussed herein" (Andrée et al., 2011, p. 139). However, significant opportunities unique to rural communities may be emerging to develop new social solidarities (Lavallée-Picard, 2016). Evidence from this case study of the MCA revealed elements of, but limitations to, these social linkages.

The producer/consumer connection can be seen in the local support for supply management in the MCA, which jells with Andrée et al.'s (2011) observation that most PFPP actors support the protected sectors. The ICSP's food sovereignty list in the MCA could offer a framework of cooperation between the NSFA and AFSC to better embed food sovereignty measures in the MCA and Town of Antigonish.

The Indigenous/non-Indigenous dichotomy was not a direct focus of this study but bears some commentary. In 2007, the Canadian food sovereignty movement added a seventh pillar (Food as Sacred) to reflect Indigenous understandings of food sovereignty (Shawki, 2015). Home to 13 Mi'kmaw communities, Nova Scotia's Indigenous population constitutes $2.7 \%$ of the province's population of approximately 900,000 (Gibson et al., 2015). As elsewhere in Canada, there is also a fraught history with dominant groups and governments in Nova Scotia (Paul, 2006). Yet, at Paqtnkek Mi'kmaw Nation, literally down the road from the Tracadie farmland development in Plates 1-3, a highly respected band councilor spoke on sustainable water and fisheries at Food Secure Canada's 2016 summit in Halifax. Generally speaking, Indigenous food systems and worldviews that value non-agrarian customs could enrich food sovereignty ideas that, to a great extent, remain grounded in private farmland ownership (Kepkiewicz \& Dale, 2019).

In regard to the Global South, a tour by Vandana Shiva, a world-renowned Indian scholaractivist, may have raised public consciousness 
around food in Nova Scotia (Interview \#6). Moreover, the local food movement centered around St. FXU, including its significant international student body, could address farmland protection as part of its emerging strategic thinking on local food security (Interview \#6). Nova Scotia residents also average among the highest annual hours of volunteering in Canada, which could be important in building the local food movement in the MCA (Gibson et al., 2015). Collective agrarian initiatives, past and present, also offer possibilities. The legacy (and limitations) of the Antigonish Movement-an early $20^{\text {th }}$ century Catholic-led social movement of fishers', workers', and farmers' cooperatives and study clubs-along with the staying power of both conventional and "new" agricultural cooperatives today, could guide $21^{\text {st }}$ century food system transformation in Nova Scotia (Cameron \& Hanavan, 2014).

Despite these grassroots developments in the MCA, the food sovereignty policy regime does not yet represent a nascent social movement. LavalléePicard's (2016) case studies found a similar social scape in rural Saint-Camille (Québec) and Salt Spring Island (British-Columbia): a mixture of dairy, conventional, and some alternative farms. These two sites exhibited a greater degree of social movement-building as encapsulated in solidarity cooperatives, community gardens, land trusts, farm centers, and conventional farmers, all organized and committed to rebooting local agricultural systems (Lavallée-Picard, 2016). Yet even the Québec and British Columbia initiatives fell short in building "food sovereignty planning" into local municipal governance (Lavallée-Picard, 2016) in contexts where provincial farmland protection and local rural solidarity were far stronger than in Nova Scotia (Connell et al., 2019).

Across Canada, food sovereignty ideas remain largely confined to public narratives around local food, social movement mobilization, or lobbying of the actually existing Canadian state. For instance, there have been calls for state-based institutionalization of food sovereignty principles into public policy to support the rights of small-scale farmers, fishers, and Indigenous peoples (Wittman, 2015). However, food sovereignty's "messiness" may not be due only to integration challenges across institutional scales of the state, but also to its weak presence as an embedded policy regime (Jochim \& May, 2010). A supply management "2.0," as raised in our findings, in effect a fusion of Keynesian and food sovereignty principles, would find little traction either provincially or federally where market liberal ideas predominate in the corridors of power (Metzger, 2017).

Food sovereignty has been critiqued for its complexity, romanticism, populism, lack of clarity, and need to do more (Desmarais, 2015). We would further add the urgency of "bringing back the (Canadian) state" as another gap, echoing VergaraCamus and Kay's (2017) reminder of the state's potentially central role for food sovereignty's prospects. While we have seen the nascent presence of a food sovereignty policy regime in rural Canada, the reality is that local food systems rarely meet the ideal form envisioned by food sovereignty proponents; localization of different policy regime mixtures alone may not lead to food sovereignty (Robbins, 2015).

State power (re)creates institutional forms, markets, and property relations in the countryside. If fledgling food sovereignty forms are to truly take root, then food sovereignty's proponents should consider, among other possibilities, the transformative potential of a democratic state to channel the fiscal capacity of public policy toward national food self-reliance, working in tandem with a broader inward convergence of the national economy itself. Most critically, political coalition-building may be necessary to embed food sovereignty ideas and actors at all government levels to effect alternative policy pathways.

Whether it is called food sovereignty or something else, a new agricultural paradigm built on consensus, combining pressure from civil society with representation in government(s), could decisively strengthen the political and economic context for long-term farmland protection in Canada.

\section{Acknowledgments}

The authors wish to thank the interviewees for their cooperation and insights, as well as GeoNova Scotia and the Eastern District Planning Commission (EDPC) for the maps. 


\section{References}

Agriculture and Agri-food Canada [AAFC]. (2020). An overview of the Canadian agriculture and agri-food sector. https://www.ourcommons.ca/content/Committee/431/AGRI/WebDoc/WD10701227/431 AGRI reldoc PDF LDepartmentOfAgricultureAndAgri-Food-e.pdf

Andrée, P., Cobb, M., Mousa, L., \& Norgang, E. (2011). Building unlikely alliances around food sovereignty in Canada. Studies in Political Economy, 88(1), 133-159. https://doi.org/10.1080/19187033.2011.11675012

Antigonish Food Security Coalition [AFSC]. (2013). A community food assessment for northeastern Nova Scotia. https://mcconnellfoundation.ca/wp-content/uploads/2017/08/Antigonish-Food-Assessment-Final-Report.pdf

Cameron, G., \& Connell, D. J. (2016). Agricultural land use planning in Canada: Case study of the municipal county of Antigonish, Nova Scotia: Final Report. Retrieved from http://www.aglup.org/nova-scotia.html

Cameron, G., \& Hanavan, L. (2014). Re-imagining rural cooperation in Atlantic Canada. Journal of Agriculture, Food Systems, and Community Development, 4(3), 29-45. https://doi.org/10.5304/jafscd.2014.043.008

Campey, L. H. (2007). After the Hector: The Scottish pioneers of Nova Scotia and Cape Breton 1773-1852 (2nd Ed.). Natural Heritage Books.

Casket, The. (2013, July 31). County approves rezoning application. Retrieved February 2015 from http://www.thecasket.ca/archives/30848 [no longer accessible]

Connell, D. J. (2016, June 20-21). National Forum on Farmland Protection in Canada: Summary of proceedings. https://www.unbc.ca/sites/default/files/sections/agricultural-land-useplanning/aglupnationalforumsummaryproceedings.pdf

Connell, D. J., \& Cameron, G. (2016). Agricultural land use planning in Canada: A case study of Municipality of the County of Kings, Nova Scotia: Final report. http://www.aglup.org/nova-scotia.html

Connell, D. J., Bryant, C., Caldwell, W., Cameron, G. \& Johnston, T. (2019). Protecting farmland in Canada: Provincial legislative frameworks. In H. McLeod-Kilmurray, A. Lee, \& N. Chalifour (Eds.), Food law and policy in Canada (pp. 113-149). Thomson Reuters Canada.

Connell, D. J., Bryant, C. R., Caldwell, W. J., Churchyard, A., Cameron, G., Johnston, T., Margulis, M. E., Ramsey, D., \& Marois, C. (2013). Food sovereignty and agricultural land use planning: The need to integrate public priorities across jurisdictions. Journal of Agriculture, Food Systems, and Community Development, 3(4), 117-124. https://doi.org/10.5304/jafscd.2013.034.011

Desmarais, A. (2015). The gift of food sovereignty. Canadian Food Studies / La Revue canadienne des études sur l'alimentation, 2(2), 154-163. https://doi.org/10.15353/cfs-rcea.v2i2.115

Desmarais, A. A., \& Wittman, H. (2014). Farmers, foodies and First Nations: Getting to food sovereignty in Canada. The Journal of Peasant Studies, 41(6), 1153-1173. https://doi.org/10.1080/03066150.2013.876623

Devanney, M. (2010). Profile of agricultural land resources in Nova Scotia. Retrieved from http://novascotia.ca/agri/documents/business-research/AL1000\%20Nova\%20Scotia.pdf

Devanney, M., \& Maynard, M. (2008). A review of initiatives intended to conserve agricultural land. Nova Scotia Agriculture. https://novascotia.ca/agri/documents/business-research/LandUseReview.pdf

Eastern District Planning Commission (EDPC). (2014). Eastern District Planning Commission 2013-2014 annual report and financial statements. http://www.edpc.ca/annualreports/Annual Report-13-14.pdf

Ekistics Planning and Design. (2010). Antigonish Exbibition Grounds: Master plan (Draft Report) [Unpublished report].

Food Secure Canada. (n.d.). What is food sovereignty. Retrieved June 2020 from https://foodsecurecanada.org/who-we-are/what-food-sovereignty

Gibson, R., Fitzgibbons, J., \& Nunez, N. R. (2015). State of rural Canada report. State of Rural Canada. https://sorc.crrf.ca/wp-content/uploads/2015/09/SORC2015NS.pdf

Jochim, A. E., \& May, P. J. (2010). Beyond subsystems: Policy regimes and governance. Policy Studies Journal, 38(2), 303327. https://doi.org/10.1111/j.1541-0072.2010.00363.x

Kepkiewicz, L., \& Dale, B. (2019). Keeping 'our' land: Property, agriculture and tensions between Indigenous and settler visions of food sovereignty in Canada. The Journal of Peasant Studies, 46(5), 983-1002.

https://doi.org/10.1080/03066150.2018.1439929 
Lavallée-Picard, V. (2016). Planning for food sovereignty in Canada? A comparative case study of two rural communities. Canadian Food Studies / La Revue canadienne des études sur l'alimentation, 3(1), 71-95. https://doi.org/10.15353/cfs-rcea.v3i1.73

Levkoe, C. (2013). Food sovereignty in Canada: Creating just and sustainable food systems [Book review]. The Journal of Peasant Studies, 40(1), 293-297. https://doi.org/10.1080/03066150.2012.725542

Library of Parliament Research Publications. (2016). An overview of the Canadian agriculture and agri-food system. No longer available online.

MacKinnon, R. (1996). Agriculture and rural change in Nova Scotia, 1851-1951. Canadian Papers in Rural History, 10, 231-274.

Malhotra, K. (2009, October). Integrated community development sustainability plan —Final draft. No longer available online.

Martin, S. J., \& Andrée, P. (2017). Putting food sovereignty to work: Civil society governmentalities and Canada's People's Food Policy Project (2008-2011). Journal of Civil Society, 13(4), 374-391. https://doi.org/10.1080/17448689.2017.1355034

Mendes, W. (2007). Negotiating a place for 'sustainability' policies in municipal planning and governance: The role of scalar discourses and practices. Space and Polity, 11(1), 95-119. https://doi.org/10.1080/13562570701406683

Metzger, M. (2017). Food sovereignty in Canada: Emerging actors and competing ideas in national agri-food policymaking [Master's thesis, University of North British Columbia]. https://prezi.com/iwpmgbr2w289/food-sovereignty-in-canada/

Mount, P. (2017). Supply management as food sovereignty. In I. Knezevic, A. Blay-Palmer, C. Levkoe, P. Mount, \& E. Nelson (Eds.), Nourishing communities: From fractured food systems to transformative pathways (pp. 147-164). Springer. https://www.springer.com/gp/book/9783319569994

Municipality of the County of Antigonish [MCA]. (1994). Eastern Antigonish County Planning area: Municipal planning strategy and land use by-law. http://www.edpc.ca/plandocs/eastern/ERMPS.pdf

MCA. (2013a). Municipal planning strategy and land use by-law for the Central Antigonish plan area in the Municipality of the County of Antigonish. http://www.edpc.ca/plandocs/central at/CentralAntigonishMPS2016.pdf

MCA. (2013b). Central Antigonish land use by-law. http://www.edpc.ca/plandocs/central at/CentralAntigonishLUB2016.pdf

National Farmers Union (NFU). (2020). National Farmers Union: Region 1: Atlantic region. https://www.nfu.ca/regions/region-1/

Nicol, A. (2006). Planning for coastal areas in the context of changing climatic conditions in Antigonish County, Final Report [Independent Project, PLAN 6000, Prepared in partial fulfillment of a Master of Planning, Dalhousie University] (Unpublished report).

Nova Scotia Department of Agriculture. (n.d.). Protecting and preserving agricultural land in Nova Scotia: A policy framework. https://www2.unbc.ca/sites/default/files/sections/agricultural-land-useplanning/protectingandpreservingagriculturallandinnsapolicyframework.pdf

Nova Scotia Department of Agriculture. (2010, November 25). Agriculture plan cultivates homegrown success [Press release]. http:// novascotia.ca/news/release/?id=20101125007

Nova Scotia Department of Municipal Affairs and Housing [NSDMAH]. (2021). Municipal Government Act: Chapter 18 of the Acts of 1998, as amended. https://www.nslegislature.ca/sites/default/files/legc/statutes/municipal\%20government.pdf

Nova Scotia Federation of Agriculture [NSFA]. (2020). Food Miles Project. https://nsfa-fane.ca/projects/food-miles-project/

NSFA. (2012a). Statistical profile of Antigonish County. No longer available online.

NSFA. (2012b). Standing Policy 2012-2013. No longer available online.

Nova Scotia Government [NSG]. (2000). Agricultural Marshland Conservation Act. Retrieved from An Act for the Conservation of Agricultural Marshland (nslegislature.ca)

NSG. (2018). Bill 58 (as passed): Municipal Government Act (amended) and Halifax Regional Municipality Charter (amended). https://nslegislature.ca/legc/bills/63rd 2nd/3rd read/b058.htm

NSG. (2020a). Agricultural land protection [Open data portal]. https://data.novascotia.ca/Agriculture-and-Agri-business/Agricultural-Land-Protection/y8ky-5igs 
NSG. (2020b). Bill No. 10 (as amended): Farm Practices Act. https://nslegislature.ca/legc/bills/58th $1 \mathrm{st} / 3 \mathrm{rd} \mathrm{read} / \mathrm{b} 010 . \mathrm{htm}$

Nova Scotia Utility and Review Board [URB]. (2020) Planning. https://nsuarb.novascotia.ca/mandates/planning

Paul, D. N. (2006). We were not the savages: Collision between European and Native American civilizations (3 ${ }^{\text {rd }}$ Ed.). Fernwood Publishing.

Robert, N., \& Mullinix, K. (2018). Municipal policy enabling regional food systems in British Columbia, Canada: Assessing focal areas and gaps. Journal of Agriculture, Food Systems, and Community Development, 8(Suppl. 2), $115-132$. https://doi.org/10.5304/jafscd.2018.08B.003

Robbins, M. J. (2015). Exploring the 'localisation’ dimension of food sovereignty. Third World Quarterly, 36(3), 449-468. https://doi.org/10.1080/01436597.2015.1024966

Rudolph, K. R., \& McLachlan, S. M. (2013). Seeking Indigenous food sovereignty: Origins of and responses to the food crisis in northern Manitoba, Canada. Local Environment, 18(9), 1079-1098. https://doi.org/10.1080/13549839.2012.754741

Statistics Canada. (2016). 2016 Census of Agriculture. https://www.statcan.gc.ca/eng/ca2016

Shawki, N. (2015). Transnationalism and diffusion: A study of the food sovereignty movements in the UK and Canada. Globalizations, 12(5), 758-773. http://dx.doi.org/10.1080/14747731.2015.1012848

Vergara-Camus, L., \& Kay, C. (2017). Agribusiness, peasants, left-wing governments, and the state in Latin America: An overview and theoretical reflections. Journal of Agrarian Change, 17(2), 239-257. https://doi.org/10.1111/joac.12215

Williams, R. B., LeBlanc, L., Bishop, P., MacDonald, C., Swetnam, W., \& van de Riet, J. (2010). Preservation of agricultural land in Nova Scotia. https://www2.unbc.ca/sites/default/files/sections/agricultural-land-useplanning/preservationofagriculturallandinns.pdf

Wittman, H. (2015). From protest to policy: The challenges of institutionalizing food sovereignty. Canadian Food Studies/La Revue canadienne des études sur l'alimentation, 2(2), 174-182. https://doi.org/10.15353/cfs-rcea.v2i2.99 